\title{
ANALISIS KONDISI KUALITAS AIR DAN PRODUKTIVITAS BUDIDAYA KERAMBA JARING APUNG DI WADUK CIRATA KABUPATEN CIANJUR PROVINSI JAWA BARAT
}

Oleh:

Iis Jubaedah, Dinno Sudinno dan Pigoselpi Anas

Dosen Jurusan penyuluhan Perikanan Sekolah tinggi Perikanan

\begin{abstract}
ABSTRAK
Penelitian mengenai analisis kondisi kulitas air dan produktivitas budidaya ikan di keramba jaring apung (KJA) telah dilakukan. Penelitian ini bertujuan untuk mengetahui kondisi kualitas perairan Waduk Cirata yang di gunakan untuk budidaya ikan di KJA, mengetahui beban pencemaran perairan, dan mengetahui kapasitas asimilasi perairan di Waduk Cirata. Metode yang digunakan dalam penelitian ini adalah metode survey. Data primer yang di kumpulkan adalah data kualitas air (kimia, fisika, biologi) dan data produksi guna menghitung produktivitas (jumlah panen / luas areal KJA). Data dianalisis dengan metode analisis deskriptif kualitatif dan kuantitatif. Data parameter kualitas air menggunakan analisis berdasarkan baku mutu air, dengan cara membandingkan nilai hasil pengukuran dari masing- masing parameter fisika, kimia dan biologi dengan Peraturan Pemerintah Provinsi Jawa Barat tentang Baku Mutu Air Tawar. Hasil analisis menunjukkan Status Kualitas Perairan Waduk Cirata memiliki nilai indeks pencemaran 14,4311 maka perairan Waduk Cirata tercemar berat, Beban pencemaran dari Parameter $\mathrm{H}_{2} \mathrm{~S}, \mathrm{NH}_{3}, \mathrm{PO}_{4}, \mathrm{NO}_{3}, \mathrm{NO}_{2}, \mathrm{Hg}, \mathrm{Pb}, \mathrm{Cu}$ lebih besar dibanding dengan kapasitas asimilasinya sehingga perairan waduk Cirata tercemar oleh parameter tersebut, Parameter kapasitas asimilasi perairan waduk Cirata yang nilainya lebih besar dari nilai beban pencemarannya adalah parameter TSS, BOD dan COD, Sedangkan produksi ikan mengalami penurunan yakni pada tahun 2004 sebanyak 13629 ton dan pada tahu 2011 sebanyak 5441 ton.
\end{abstract}

Kata kunci : kualitas perairan, produktivitas, budidaya KJA, Waduk Cirata

\section{PENDAHULUAN}

\section{Latar Belakang}

Pembangunan

sumberdaya yang

mensyaratkan bahwa pengelolaan sumberdaya tidak hanya menghasilkan kemakmuran bagi generasi sekarang tapi harus dapat dinikmati oleh generasi mendatang. Oleh karena itu, pembangunan atau pengelolaan harus menguntungkan secara ekonomi, ekologi dan sosial. Dalam konteks pengelolaan sumberdaya perairan berkelanjutan, secara teknis adalah suatu upaya pemanfaatan sumberdaya alam dan jasa lingkungan yang terdapat di wilayah perairan tersebut untuk kesejahteraan manusia, terutama stakeholder, sedemikian rupa, sehingga laju (tingkat) pemanfaatannya tidak melebihi daya dukung perairan yang merupakan fungsi dari luas wilayah perairan, kandungan sumber alam, kapasitas asimilasi limbah, penggunaan teknologi dan fungsi-fungsi penunjang kehidupan lainnya. 
Sumber daya perikanan merupakan sumberdaya yang dapat pulih dan tidak akan punah jika dimanfaatkan pada kondisi optimal. Jika pemanfaatan yang dilakukan lebih besar dari tingkat pertumbuhan (daya pulih), maka dalam jangka waktu tertentu sumberdaya perikanan akan bisa punah. Pembangunan yang berkelanjutan merupakan arah kebijakan pembangunan sektor kelautan dan perikanan kedepan. Oleh karena itu diperlukan kewaspadaan dan kehati- hatian dalam pengelolaan nya.

Budidaya ikan dalam KJA akhirakhir ini berkembang dengan sangat pesat, termasuk di Waduk Cirata dimana kegiatan budidaya ikan dalam KJA paling banyak di lakukan. Limbah yang berasal dari KJA akan sangat mempengaruhi kualitas perairan Waduk Cirata. Menurud Mc Donald et al., (1996) dalam Simarmata (2007), bahwa $30 \%$ dari jumlah pakan yang di berikan tertinggal sebagai pakan yang tidak di konsumsi dan 25 - $30 \%$ dari pakan yang di konsumsi akan diekskresikan. Hal ini menunjukkan jumlah yang cukup besar dari sisa pakan tersebut masuk ke perairan.

Agar pengelolaan Waduk Cirata dapat dilakukan secara berkelanjutan dan lestari, penelitian ini menjadi penting guna menganalisis kondisi kualitas perairan dan mengetahui produktivitas budidaya ikan di Waduk Cirata.

\section{Rumusan Masalah}

Waduk Cirata berada di tengahtengah Daerah Aliran Sungai Citarum, Waduk ini di kelola oleh 3 Kabupaten yaitu Kabupaten Cianjur, Kabupaten
Bandung dan Kabupaten Purwakarta. Adanya kegiatan budidaya ikan dalam Karamba Jaring Apung di Waduk Cirata ini mengakibatkan terjadinya penurunan kualitas air waduk, pendangkalan waduk, dan lain- lain. Kondisi ini berdampak pada ikan yang hidup di dalam perairan tersebut akan mengalami stress, mudah terserang penyakit dan akhirnya mempengaruhi hasil panen. Salah satu penyebab menurunnya kualitas air Waduk Cirata, di duga karena banyaknya limbah organik yang berasal dari sisa pakan budidaya KJA yang terbuang ke dalam perairan. Untuk mendapatkan ikan dengan pertumbuhan yang optimal, terhindar dari berbagai penyakit, maka di perlukan lingkungan dengan kualitas air yang baik dan mendukung kehidupan ikan.

\section{Tujuan Penelitian}

Penelitian ini bertujuan untuk :

a. Mengetahui kondisi kualitas perairan Waduk Cirata yang di gunakan untuk budidaya Keramba Jaring Apung (KJA).

b. Mengetahui beban pencemaran perairan Waduk Cirata

c. Mengetahui kapasitas asimilasi perairan Waduk Cirata

d. Mengetahui kecendrungan produksi KJA di Waduk Cirata.

\section{METODE PENELITIAN}

\section{Waktu Dan Tempat Penelitian}

Penelitian ini di lakukan di perairan Waduk Cirata, Jawa Barat selama 4 bulan mulai bulan Maret sampai dengan Juni 2013. 


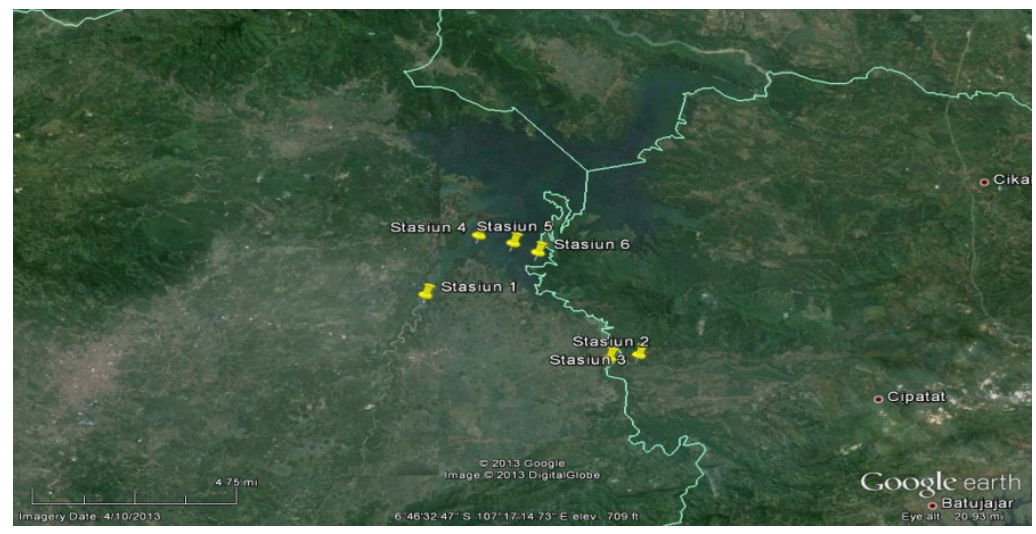

Gambar 1. Lokasi stasiun penelitian.

Jenis Dan Sumber Data.

Data yang di gunakan dalam penelitian ini terdiri dari data primer dan data sekunder. Data primer diperoleh dengan cara pengukuran, pengamatan, dan wawancara dengan narasumber (pembudidaya dan instansi terkait) pada saat penelitian berlangsung. Data primer yang di kumpulkan adalah data kualitas air (kimia, fisika, biologi) dan data produksi guna menghitung produktivitas (jumlah panen / luas areal KJA) pada saat penelitian di lakukan. Data sekunder diambil untuk beberapa tahun terakhir yang meliputi data produksi dan kualitas air di peroleh dari instansi terkait sesuai dengan tujuan penelitian.

\section{Teknik Sampling dan Metode Pengambilan Data}

Pengambilan sampel di lakukan pada beberapa stasiun berdasarkan pertimbangan bahwa, stasiun yang di tetapkan di anggap mewakili daerah sekitarnya. Pada setiap stasiun di lakukan pengambilan contoh air, contoh sedimen dan biota air berupa plankton . pengukuran parameter kualitas air di lakukan dengan cara in situ dan analisis di laboratorium.

\section{Analisis Data}

Data yang di peroleh pada penelitian ini dianalisis dengan metode analisis deskriptif dan statistik. Data parameter kualitas air menggunakan analisis berdasarkan buku mutu air, dengan cara membandingkan nilai hasil pengukuran dari masing- masing parameter fisika, kimia dan biologi dengan Peraturan Pemerintah Provinsi Jawa Barat tentang Baku Mutu Air Tawar. Hasil pengukuran di sajikan dalam bentuk tabel, grafik yang memuat semua nilai hasil pengukuran parameter fisika, kimia dan biologi perairan. Pada tabel yang sama, di cantumkan pula nilai baku mutu untuk masing- masing parameter sehingga dapat di bandingkan antara hasil pengukuran dan nilai mutu sehingga dapat di ketahui kondisi kualitas air Waduk Cirata.

\section{Analisis kualitas air}

Parameter kualitas air yang diamati yaitu parameter Fisik: kecerahan, suhu, dan TSS; parameter Kimia: $\mathrm{pH}$, Oksigen terlarut, BOD dan COD. 
Tabel 1. Parameter Kualitas Air yang Diamati

\begin{tabular}{|c|l|c|l|c|}
\hline No & \multicolumn{1}{|c|}{ Parameter } & Satuan & \multicolumn{1}{|c|}{ Alat/Cara Analisis } & Keterangan \\
\hline A. & Fisika & & & \\
\hline 1. & Kecerahan & $\mathrm{cm}$ & Secchi disk & In situ \\
\hline 2. & $\mathrm{Suhu}$ & ${ }^{\circ} \mathrm{C}$ & Thermometer & In situ \\
\hline 3. & $(\mathrm{TSS})$ & $\mathrm{mg} / 1$ & Gravimetri & Laboratorium \\
\hline B. & Kimia & & & In situ \\
\hline 4. & $\mathrm{pH}$ & - & $\mathrm{pH}$ meter & In situ \\
\hline 5. & $\mathrm{Oksigen} \mathrm{terlarut}$ & $\mathrm{Mg} / 1$ & DO meter & Laboratorium \\
\hline 6. & $\mathrm{NO}_{2}$ & $\mathrm{mg} / 1$ & JIS. NO. K0102. 43.2.4 & Laboratorium \\
\hline 7. & $\mathrm{BOD}$ & $\mathrm{mg} / 1$ & Botol sampel $;$ Titrimetrik & Laboratorium \\
\hline 8. & $\mathrm{COD}$ & $\mathrm{mg} / 1$ & Botol sampel; Titrimetrik & Laboratorium \\
\hline 9 & $\mathrm{Ammonia}$ & $\mathrm{mg} / 1$ & SNI. 06-6989-30-2005 & Laboratorium \\
\hline 10 & $\mathrm{Phospat}$ & $\mathrm{mg} / 1$ & APHA 4500-PO -2005 & Laboratorium \\
\hline 11 & $\mathrm{NO} 3$ & $\mathrm{mg} / 1$ & JIS. NO. K0102. 43.2.4 & \\
\hline $\mathbf{C}$ & $\mathbf{L o g a m}$ & & & Laboratorium \\
\hline 12 & $\mathrm{Hg}$ & $\mathrm{mg} / 1$ & APHA. 3114B-2005 & Laboratorium \\
\hline 13 & $\mathrm{~Pb}$ & $\mathrm{mg} / 1$ & APHA. 3120B-2005 & Laboratorium \\
\hline 14 & $\mathrm{Cu}$ & $\mathrm{mg} / 1$ & APHA. 3120B-2005 & \\
\hline
\end{tabular}

\section{Status Mutu Air}

Pedoman yang digunakan untuk mengetahui status mutu air adalah Keputusan Menteri Negara Lingkungan Hidup Nomor : 115 Tahun 2003 tentang Pedoman Penentuan Status Mutu Air, disebutkan bahwa Indeks Pencemaran (IP) adalah indeks yang digunakan untuk menentukan tingkat pencemaran relatif terhadap parameter kualitas air yang diizinkan. Indeks ini memiliki konsep yang berlainan dengan Indeks Kualitas Air. Indeks Pencemaran ditentukan untuk suatu peruntukan, kemudian dapat dikembangkan untuk beberapa peruntukan bagi seluruh bagian badan air atau sebagian dari suatu perairan. Nilai Indeks Pencemaran dapat dihitung dengan rumus :

$$
I_{X}=\frac{\sqrt{\left(\frac{C i}{L_{x}}\right)_{M}^{2}+\left(\frac{C i}{L_{x}}\right)_{R}^{2}}}{2}
$$

Dengan :

IPx = Indeks Pencemaran peruntukan air (x), Ci = Konsentrasi parameter kualitas air (i) dari suatu perairan yang akan dinilai, Lix $=$ Konsentrasi parameter sesuai baku mutu air peruntukan (x); $\mathbf{M}=$ Maksimum; $\mathbf{R}=$ Rata-rata

Evaluasi terhadap nilai Indeks Pencemaran adalah : a) $0 \leq \mathrm{IP} \leq 1,0=$ Memenuhi baku mutu (kondisi baik); b) $1,0<\mathrm{IP} \leq 5,0=$ Cemar ringan; c) $5,0<\mathrm{IP} \leq 10,0=$ Cemar sedang d) IP $>10,0=$ Cemar berat.

\section{Analisis Beban Pencemar}

Analisis beban pencemaran dilakukan dengan perhitungan secara langsung di perairan. Cara penghitungan beban pencemaran ini didasarkan atas pengukuran debit sungai dan konsentrasi limbah di muara sungai berdasarkan persamaan (Mitsch \& Goesselink, 1993) dalam Marganof (2007).

Keterangan:

$$
\mathrm{BP}=\mathrm{Q} \times \mathrm{C}
$$

$\mathrm{BP}=$ beban pencemaran $; \mathrm{Q}=$ debit sungai (m3/detik); $\mathrm{C}=$ konsentrasi limbah ( $\mathrm{mg} /$ liter $)$

\section{Kapasitas Asimilasi}

Untuk menghitung kapasitas asimilasi perairan terhadap beban pencemaran dilakukan dengan menggunakan metode hubungan antara konsentrasi parameter limbah di perairan dengan beban limbah di muara sungai. 
Nilai kapasitas asimilasi didapatkan dengan cara membuat grafik hubungan antara nilai konsentrasi masing-masing parameter limbah di perairan dengan parameter limbah tersebut di muara sungai. Selanjutnya dianalisis dengan memotongkan dengan garis nilai baku mutu air seperti diperlihatkan pada

Gambar 2.



Gambar 2. Hubungan antara beban pencemaran dan konsentrasi pencemar.

\section{HASIL DAN PEMBAHASAN}

\section{Kondisi Umum Wilayah}

Waduk Cirata mendapat sumber air dari daerah aliran Sungai Citarum. Waduk ini merupakan waduk ketiga setelah Jatiluhur dan Saguling yang dibangun dengan membendung aliran Sungai Citarum Waduk Cirata yang dibangun pada 1982 - 1987 itu berada di ketinggian $221 \mathrm{~m}$ dari permukaan laut. Luasnya 6.200 hektar (ha) dengan luas tangkapan air 603.200 ha, kedalaman rata-rata $34,9 \mathrm{~m}$, dan volume 230 ribu $\mathrm{m}^{3}$. Wilayah genangan airnya meliputi Kabupaten Cianjur, Purwakarta, dan Bandung. Namun, wilayah genangan air terluas berada di Cianjur (60\%), Bandung (25\%) dan Purwakarta (15\%)

Sejak menjadi genangan

permanen, Waduk Cirata berkarakteristik perairan umum. Karena itu, Cirata memiliki berbagai potensi di bidang sosial ekonomi, seperti sumber pengairan sawah, air bersih, air minum, tempat budidaya ikan, wahana rekreasi, dan sarana perhubungan.

\section{Potensi Perikanan}

Waduk Cirata, yang mulai difungsikan pada 1988, sejatinya menyimpan potensi ekonomi yang tidak kecil. Akhir September 2006, Menteri Kelautan dan Perikanan Freddy Numberi, menyebutkan, usaha budidaya ikan di Cirata melibatkan tenaga kerja langsung sekitar 2.100 orang. Volume produksinya rata-rata 6.450 ton ikan per bulan, dan perputaran uang Rp1,3 triliun per tahun.

Budidaya ikan di Waduk Cirata dilakukan dengan sistem keramba jaring apung (KJA). Perkembangan KJA di 
Waduk Cirata terbilang sangat cepat, pada tahun 2003 jumlah KJA di Waduk Cirata sebanyak 38286 unit, jumlah ini sudah menutupi permukaan Waduk Cirata sebesar $15-20 \%$. Badan Pengelola Waduk Cirata (BPWC) mencatat, jumlah KJA di Cirata saat ini mencapai 50.000 petak kolam atau 12.500 unit. "Dari jumlah KJA itu, 60\%nya, atau 30.000 petak kolam. Cianjur menyubang $39,5 \%$ terhadap produksi perikanan KJA Jabar. Dinas perikanan Provinsi jabar mencatat, produksi ikan KJA pada tahun 2007 hampir 144 ribu ton. Dari jumlah itu, 57000 ton diantaranya, senilai Rp. 353,05 miyar, berasal dari aktivitas di KJA Cianjur. Jenis ikan yang biasa di budidayakan adalah ikan mas (Cyprinus carpio) dan ikan nila (Oreochromin niloticus). Berdasarkan pengamatan dan informasi dari penduduk terdapat berbagai macam jenis ikan di waduk Cirata seperti: ikan mujair (Orechromis sp) nilem (Osteicthchilus hasselty), tawes (Puntius sp), gabus (Pangasius sp), dan ikan hampal (Hampala macrolepidota).

\section{Kondisi Kualitas Perairan Waduk Cirata}

Pengamatan dan pengukuran kualitas air dilakukan di 6 (enam) stasiun yang dianggap mewakili daerah sekitarnya. Pengukuran parameter suhu, $\mathrm{pH}$, kelarutan oksigen, kecerahan air dilakukan secara in situ, sedangkan parameter lainnya dilakukan di laboratorium. Hasil pengukuran parameter kualitas air Waduk Cirata disajikan pada Tabel 2

Tabel 2 Kualitas Air di Lokasi Penelitian Tahun 2013

\begin{tabular}{|c|c|c|c|c|c|c|}
\hline Parameter & St 1 & St 2 & ST 3 & ST 4 & ST 5 & ST 6 \\
\hline $\mathrm{pH}$ & 7,40 & 7,63 & 7,68 & 7,18 & 7,6 & 7,5 \\
\hline $\mathrm{Suhu}$ & 28,1 & 28,9 & 27,6 & 28,1 & 28,8 & 28,1 \\
\hline $\mathrm{TSS}$ & 85 & 33 & 75 & 20 & 16 & 10 \\
\hline $\mathrm{DO}$ & 3,20 & 4,50 & 4,10 & 3,60 & 5,9 & 4,00 \\
\hline $\mathrm{COD}$ & 14,81 & 22,22 & 24,44 & 16,67 & 17,99 & 14,81 \\
\hline $\mathrm{BOD}$ & 7,41 & 15,55 & 19,55 & 6,67 & 12,31 & 10,37 \\
\hline $\mathrm{H}_{2} \mathrm{~S}$ & 0,08 & 0,01 & 0,075 & 0,01 & 0,02 & 0,03 \\
\hline $\mathrm{NH}_{3}$ & 0,003 & 0,002 & 0,007 & 0,007 & 0,01 & 0,002 \\
\hline $\mathrm{NO}_{2}$ & 0,01 & 0,38 & 0,08 & 0,03 & 0,14 & 0,043 \\
\hline $\mathrm{NO}_{3}$ & 1,84 & 2,07 & 5,75 & 1,15 & 2,30 & 2,07 \\
\hline $\mathrm{PO}_{4}$ & 0,23 & 0,11 & 0,24 & 0,23 & 0,22 & 0,18 \\
\hline $\mathrm{Hg}$ & 0,09 & 0,27 & 0,54 & 0,05 & 0,09 & 0,07 \\
\hline $\mathrm{Pb}^{\mathrm{Cu}}$ & 0,03 & 0,03 & 0,07 & 0,02 & 0,04 & 0,01 \\
\hline
\end{tabular}

Hasil perhitungan tingkat Air dengan Metoda Indeks Pencemaran.

pencemaran perairan terdapat pada

Tabel 3. Pedoman yang digunakan untuk mengetahui tingkat pencemaran di perairan Waduk Cirata adalah Keputusan Menteri Negara Lingkungan Hidup Nomor : 115 Tahun 2003 tentang Pedoman Penentuan Status Mutu Air, I yaitu mengenai Penentuan Status Mutu
Dalam Keputusan Menteri Negara Lingkungan Hidup Nomor : 115 Tahun 2003 tentang Pedoman Penentuan Status Mutu Air, disebutkan bahwa Indeks Pencemaran (IP) adalah indeks yang digunakan untuk menentukan tingkat pencemaran relatif terhadap parameter kualitas air yang diizinkan. Indeks ini 
memiliki konsep yang berlainan dengan Indeks Kualitas Air. Indeks Pencemaran ditentukan untuk suatu peruntukan, kemudian dapat dikembangkan untuk beberapa peruntukan bagi seluruh bagian badan air atau sebagian dari suatu perairan.

Tabel 3. Indeks Pencemaran Perairan Waduk Cirata

\begin{tabular}{|c|c|c|c|c|c|c|}
\hline No & Parameter & Satuan & $\begin{array}{c}\mathbf{C i} \\
\text { rata-rata }\end{array}$ & Lix & $\mathrm{Ci} / \mathrm{Lix}$ & IP \\
\hline 1 & $\mathrm{pH}$ & - & 7,49 & 8 & 0,93 & \multirow{13}{*}{14,4311} \\
\hline 2 & Suhu & ${ }^{\circ} \mathrm{C}$ & 28,2 & 30 & 0,94 & \\
\hline 3 & TSS & $\mathrm{Mg} / \mathrm{l}$ & 39,8 & 80 & 0,49 & \\
\hline 4 & $\overline{\mathrm{DO}}$ & $\mathrm{Mg} / \mathrm{l}$ & 4,21 & 6 & 0,70 & \\
\hline 5 & COD & $\mathrm{Mg} / \mathrm{l}$ & 18,49 & 20 & 0,92 & \\
\hline 6 & BOD & $\mathrm{Mg} / \mathrm{l}$ & 11,9 & 40 & 0,29 & \\
\hline 7 & $\mathrm{H}_{2} \mathrm{~S}$ & $\mathrm{Mg} / \mathrm{l}$ & 0,03 & 0,002 & 17,9 & \\
\hline 8 & $\mathrm{NH}_{3}$ & $\mathrm{Mg} / \mathrm{l}$ & 0,005 & 0,02 & 0,25 & \\
\hline 9 & $\mathrm{NO}_{2}$ & $\mathrm{Mg} / \mathrm{l}$ & 0,11 & 0,06 & 1,89 & \\
\hline 10 & $\mathrm{NO}_{3}$ & $\mathrm{Mg} / \mathrm{l}$ & 2,53 & 1 & 2,53 & \\
\hline 11 & $\mathrm{PO}_{4}$ & $\mathrm{Mg} / \mathrm{l}$ & 0,20 & 0,01 & 20 & \\
\hline 12 & $\mathrm{Hg}$ & $\mathrm{Mg} / \mathrm{l}$ & 0,19 & 0,03 & 6,33 & \\
\hline 13 & $\mathrm{~Pb}$ & $\mathrm{Mg} / \mathrm{l}$ & 0,03 & 0,03 & 1 & \\
\hline 14 & $\mathrm{Cu}$ & $\mathrm{Mg} / \mathrm{l}$ & 0,05 & 0,02 & 2,73 & \\
\hline
\end{tabular}

$\mathrm{Ci} /$ Lix rata-rata $=4,064$

Ci/Lix Maksimum $=20$

Berdasarkan perhitungan diatas, nilai indeks pencemaran $(14,4311)$ maka perairan Waduk Cirata dikategorikan tercemar berat. Hasil penelitian Puslitbang Sumber Daya Air (PSDA) menunjukkan, kandungan oksigen air Cirata kurang dari $3 \mathrm{mg}$ per liter. Sedangkan angka normal agar ikan dapat hidup adalah $6 \mathrm{mg}$ per liter. Artinya pencemaran di Cirata bertambah berat. Penelitian atas dasar kandungan senyawa nitrogen $(\mathrm{N})$, posfat $(\mathrm{P})$, dan senyawa organik lainnya, Cirata digolongkan dalam kategori eutrophic (penyuburan berat) atau dengan kata lain pencemarannya "berat".

Penurunan kualitas air di waduk Cirata ini dapat terjadi karena melimpahnya limbah organik sisa pakan sehingga beban Waduk Cirata untuk menguraikan bahan-bahan organik (proses dekomposisi bahan organik) tersebut menjadi berat karena diperlukan oksigen. Dilihat dari pakan yang diberikan pada ikan budidaya maka budidaya ikan pada KJA di Waduk Cirata masuk ke dalam sistem budidaya KJA intensif. Frekuensi pemberian pakan menggunakan pellet yang mengandung protein tinggi ( $>20 \%$ ) adalah rata-rata tiga kali sehari bahkan bisa lebih. Kualitas air di waduk Cirata lebih banyak dipengaruhi oleh limbah yang berasal dari kegiatan budidaya ikan dalam KJA dibandingkan oleh limbah lainnya. Hal ini sesuai dengan penyataan Garno (2000), diantara kesemua penyumbang bahan organik di Waduk Cirata, penyumbang paling besar berasal dari kegiatan budidaya ikan dalam KJA. Selanjutnya dikatakan sumbangan bahan 
organik dari KJA di Waduk Cirata mencapai $80 \%$.

Penghitungan beban pencemaran dari parameter limbah TSS COD ,BOD, TSS, $\mathrm{PO}_{4}, \mathrm{NH}_{3}, \mathrm{NO}_{3}, \mathrm{NO}_{2}, \mathrm{H}_{2} \mathrm{~S}, \mathrm{Hg}$,
$\mathrm{Pb}$ dan $\mathrm{Cu}$ dihitung berdasarkan perkalian antara debit sungai dengan konsentrasi parameter kualitas air yang diteliti. Untuk lebih jelasnya dapat dilihat pada Tabel 4.

Tabel 4. Beban Pencemaran Perairan waduk Cirata ( Ton / Hari )

\begin{tabular}{|c|c|c|c|c|c|}
\hline No & Parameter & St 1 & St 2 & St 3 & Total \\
\hline 1 & $\mathrm{TSS}$ & 2100 & 1539 & 713 & 4352 \\
\hline 2 & $\mathrm{COD}$ & 366 & 1036 & 232 & 1634 \\
\hline 3 & $\mathrm{BOD}$ & 183 & 725 & 186 & 1094 \\
\hline 4 & $\mathrm{H}_{2} \mathrm{~S}$ & 0,5 & 0,7 & 2 & 3,2 \\
\hline 5 & $\mathrm{NH}_{3}$ & 0,074 & 0,093 & 0,066 & 0,233 \\
\hline 6 & $\mathrm{NO}_{2}$ & 0,24 & 18 & 0,76 & 19 \\
\hline 7 & $\mathrm{NO}_{3}$ & 45 & 96 & 55 & 196 \\
\hline 8 & $\mathrm{PO}_{4}$ & 6 & 5 & 2 & 13 \\
\hline 9 & $\mathrm{Hg}$ & 2 & 12 & 5 & 19 \\
\hline 10 & $\mathrm{~Pb}$ & 0,7 & 1,4 & 0,6 & 2,7 \\
\hline 11 & $\mathrm{Cu}$ & 1 & 2,3 & 0,5 & 3,8 \\
\hline
\end{tabular}

\section{Pendugaan Kapasitas Asimilasi}

\section{Perairan}

Penentuan kapasitas asimilasi untuk TSS dilakukan dengan persamaan regresi $\mathrm{Y}=4,8684+0,0072 \mathrm{X}$ dengan $\mathrm{R}^{2}=1$. Hasil perpotongan garis regresi dengan garis nilai baku mutu TSS (80 $\mathrm{mg} / \mathrm{l})$ menghasilkan nilai kapasitas asimilasi sebesar 10.435 ton per hari. Hal ini menunjukkan bahwa perairan waduk Cirata tidak tercemar oleh bahan pencemar TSS. 

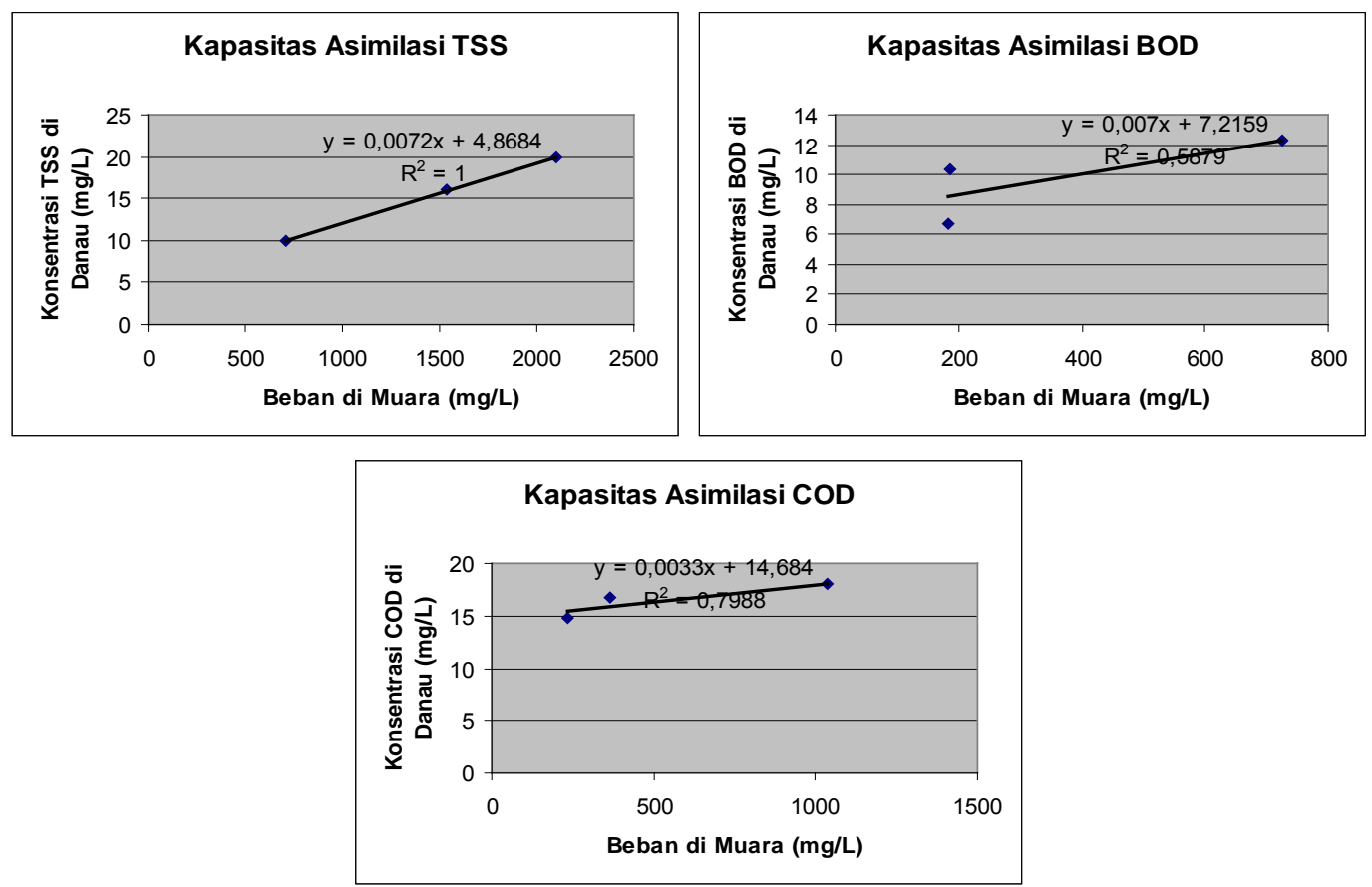

Gambar 3. Grafik hubungan konsentrasi dengan beban pencemar TSS, BOD dan COD

Penentuan kapasitas asimilasi untuk BOD dilakukan dengan persamaan regresi $\mathrm{Y}=7,2159+0,007 \mathrm{X}$ dengan $\mathrm{R}^{2}$ $=0,6079$. Hasil perpotongan garis regresi dengan garis baku mutu BOD (20 mg/l) menghasilkan nilai kapasitas asimilasi sebesar 1826 ton per hari. Hal ini menunjukkan bahwa perairan Waduk Cirata tidak tercemar oleh bahan pencemar yang mudah terurai (BOD). Penentuan kapasitas asimilasi untuk COD dilakukan dengan persamaan regresi $\mathrm{Y}=14,684+0,0033 \mathrm{X}$ dengan $\mathrm{R}^{2}=0,7988$. Hasil perpotongan garis regresi dengan garis nilai baku mutu

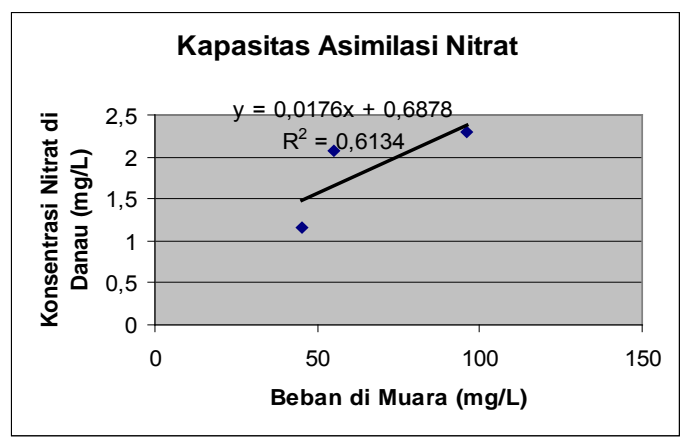

COD (40 mg/l) menghasilkan nilai kapasitas asimilasi sebesar 7671 ton per hari. Hal ini menunjukkan bahwa perairan Waduk Cirata tidak tercemar oleh bahan organik sulit terurai (COD). (Gambar 3)

Penentuan kapasitas asimilasi untuk $\mathrm{PO}_{4}$ dilakukan dengan persamaan regresi $\mathrm{Y}=0,155+0,0127 \mathrm{X}$ dengan $\mathrm{R}^{2}$ $=0,99$. Hasil perpotongan garis regresi dengan garis baku mutu $\mathrm{PO}_{4}(0,01 \mathrm{mg} / \mathrm{l})$ menghasilkan nilai kapasitas asimilasi sebesar $-11,4$ ton per hari. Hal ini menunjukkan bahwa perairan Waduk Cirata tercemar oleh Fosfat (Gambar 4).

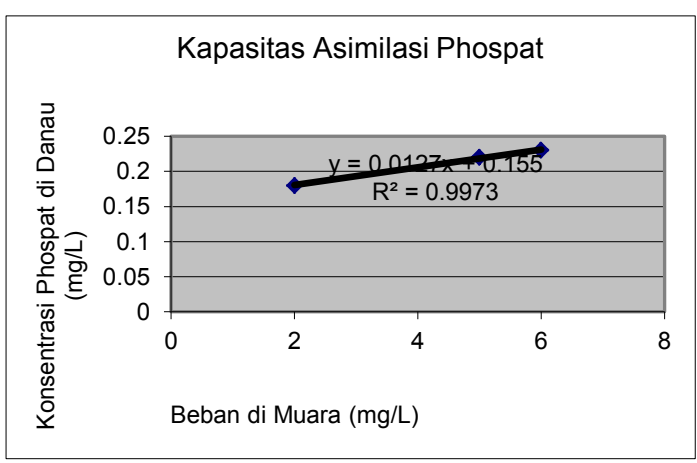

Gambar 4. Grafik hubungan konsentrasi dengan beban pencemar $\mathrm{PO}_{4}, \mathrm{NO}_{3}$ 
Penentuan kapasitas asimilasi untuk $\mathrm{NO}_{3}$ dilakukan dengan persamaan regresi $\mathrm{Y}=0,6878+0,0176 \mathrm{X}$ dengan $\mathrm{R}^{2}$ $=0,6134$. Hasil perpotongan garis regresi dengan garis baku mutu $\mathrm{NO}_{3}$ (1 mg/l) menghasilkan nilai kapasitas asimilasi sebesar 17,7 ton per hari Hal ini menunjukkan bahwa perairan waduk Cirata tercemar oleh nitrat (Gambar 4)

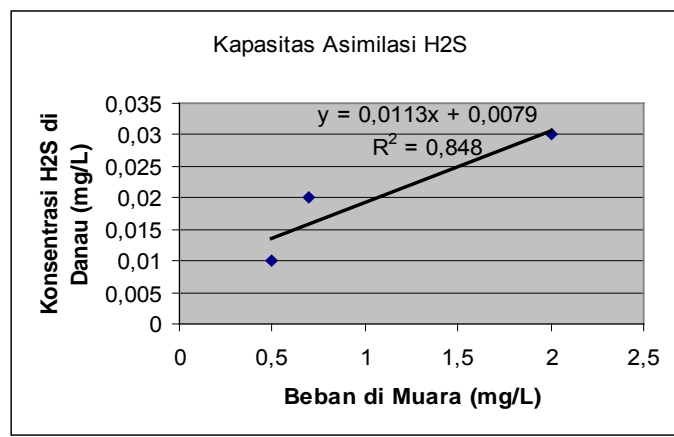

Penentuan kapasitas asimilasi untuk $\mathrm{NH}^{-}$ 3 dilakukan dengan persamaan regresi $\mathrm{Y}$ $=0,0147+0,2712 \mathrm{X}$ dengan $\mathrm{R}^{2}=0,86$. Hasil perpotongan garis regresi dengan garis baku mutu $\mathrm{NH}_{3} \quad(0,02 \mathrm{mg} / \mathrm{l})$ menghasilkan nilai kapasitas asimilasi sebesar 0,0195 ton per hari Hal ini menunjukkan bahwa perairan Waduk Cirata tercemar oleh $\mathrm{NH}_{3}$ (Gambar 5).

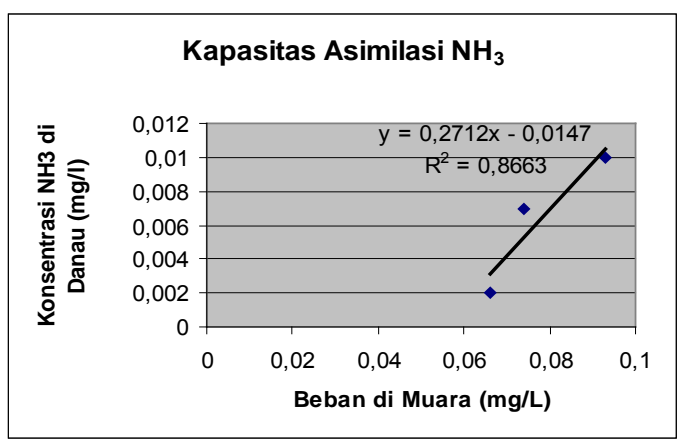

Gambar 5. Grafik hubungan konsentrasi dengan beban pencemar $\mathrm{NH}_{3}, \mathrm{H}_{2} \mathrm{~S}$

Penentuan kapasitas asimilasi untuk $\mathrm{H}_{2} \mathrm{~S}$ dilakukan dengan persamaan regresi $\mathrm{Y}=0,0079+0,0113 \mathrm{X}$ dengan $\mathrm{R}^{2}=0,84$. Hasil perpotongan garis regresi dengan garis baku mutu $\mathrm{H}_{2} \mathrm{~S}$ $(0,02 \mathrm{mg} / \mathrm{l})$ menghasilkan nilai kapasitas asimilasi sebesar $-0,522$ ton per hari Hal ini menunjukkan bahwa perairan Waduk Cirata tercemar oleh $\mathrm{H}_{2} \mathrm{~S}$ (Gambar 5)

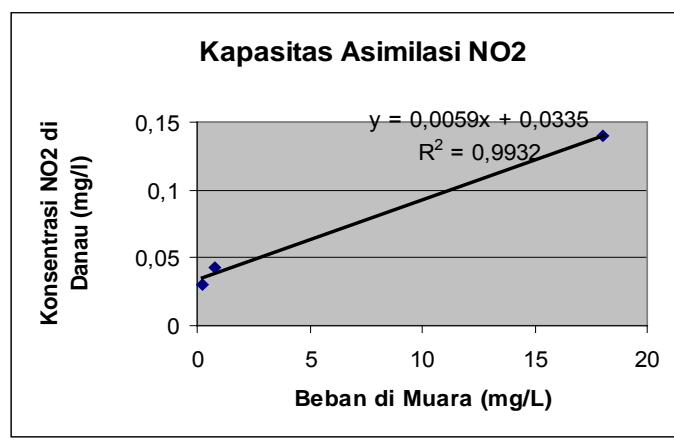

Penentuan kapasitas asimilasi untuk $\mathrm{NO}_{2}$ dilakukan dengan persamaan regresi $\mathrm{Y}=0,0335+0,0059 \mathrm{X}$ dengan $\mathrm{R}^{2}=0,99$. Hasil perpotongan garis regresi dengan garis baku mutu $\mathrm{NO}_{2}$ $(0,06 \mathrm{mg} / \mathrm{l})$ menghasilkan nilai kapasitas asimilasi sebesar 4,5 ton per hari Hal ini menunjukkan bahwa perairan Waduk Cirata tercemar oleh $\mathrm{NO}_{2}$. (Gambar 6)



Gambar 6. Grafik hubungan konsentrasi dengan beban pencemar $\mathrm{NO}_{2}, \mathrm{Hg}$

Penentuan kapasitas asimilasi untuk $\mathrm{Hg}$ dilakukan dengan persamaan regresi $\mathrm{Y}=0,0459+0,0038 \mathrm{X}$ dengan $\mathrm{R}^{2}=0,94$. Hasil perpotongan garis regresi dengan garis baku mutu $\mathrm{Hg}(0,03$ $\mathrm{mg} / \mathrm{l})$ menghasilkan nilai kapasitas asimilasi sebesar $-4,2$ ton per hari Hal ini menunjukkan bahwa perairan waduk 
Cirata tercemar oleh $\mathrm{Hg}$ (Gambar 6) Penentuan kapasitas asimilasi untuk $\mathrm{Pb}$ dilakukan dengan persamaan regresi $\mathrm{Y}=$ 0,0075 - 0,0342 $\mathrm{X}$ dengan $\mathrm{R}^{2}=0,95$ Hasil perpotongan garis regresi dengan garis baku mutu $\mathrm{Pb} \quad(0,03 \quad \mathrm{mg} / \mathrm{l})$ menghasilkan nilai kapasitas asimilasi sebesar 0,65 ton per hari. Sedangkan penentuan kapasitas asimilasi untuk $\mathrm{Cu}$ dilakukan dengan persamaan regresi $\mathrm{Y}=$ $14,684+0,0033 \mathrm{X}$ dengan $\mathrm{R}^{2}=0,79$ Hasil perpotongan garis regresi dengan garis baku mutu $\mathrm{Cu} \quad(0,02 \mathrm{mg} / \mathrm{l})$ menghasilkan nilai kapasitas asimilasi sebesar $-4,4$ ton per hari Hal ini menunjukkan bahwa perairan waduk Cirata tercemar oleh $\mathrm{Pb}$ dan $\mathrm{Cu}$ (Gambar 7).
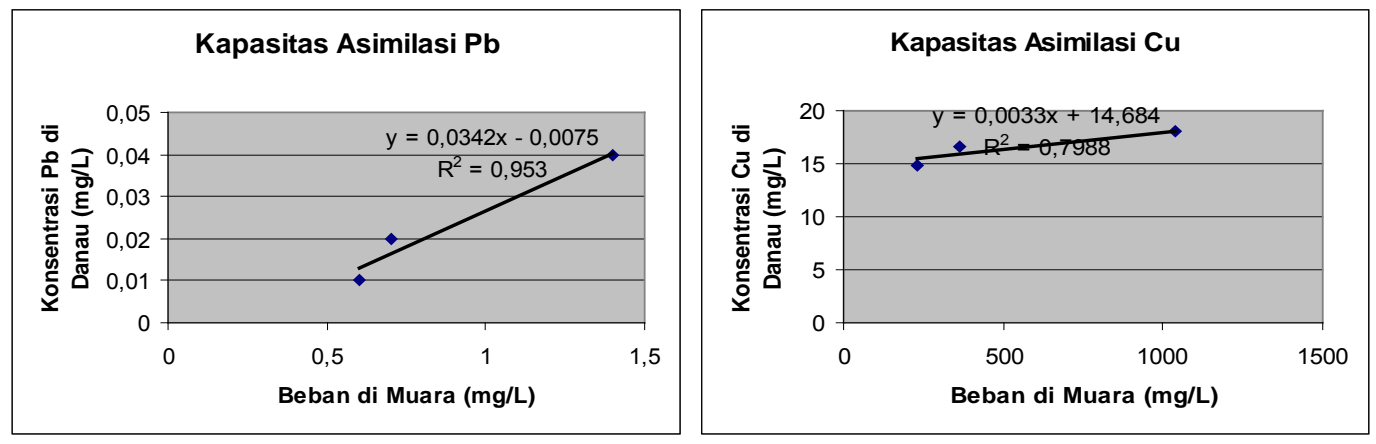

Gambar 7. Grafik hubungan konsentrasi dengan beban pencemar $\mathrm{Pb}$ dan $\mathrm{Cu}$

\section{Produksi ikan di karamba jaring apung}

Kegiatan budidaya ikan di KJA Waduk Cirata terus di upayakan karena merupakan salah satu daerah produksi ikan-ikan air tawar, sekitar 30 \% ikan ikan air tawar di wilayah Jawa Barat berasal dari Waduk Cirata. Teknologi budidaya jaring apung sudah mulai diaplikasikan di Waduk Cirata pada tahun 1986. Pada umumnya kontruksi KJA menggunakan rangka besi, dengan drum sebagai pelampung. Namun ada beberapa KJA yang mengganti drum dengan tumpukan - tumpukan stereofoam, dikarenakan mahalnya harga drum besi. Luasan KJA 1 petak $=7 \mathrm{x} 7$ meter dengan luas jaring 200 meter kedalaman 7 meter. Jaring terdiri dari 2 lapisan hal ini ditujukkan untuk mengurangi pengendapan pakan terbuang. Tujuan awal pengembangan jaring apung di Waduk Cirata adalah memberikan lapangan kerja baru bagi penduduk yang terkena proyek pembangunan PLTA tersebut. Perkembangan jumlah keramba jaring apung pada tahun 1999 di Waduk Cirata (28.739 petak) sudah melebihi dari tingkat yang direkomendasikan oleh UPTD Kabupaten Cianjur (6200 petak). Jumlah KJA pada tahun 2009 mencapai 51.418 petak dan yang masih operasional sekitar 60 persen atau sebanyak 30.850 petak dengan jumlah rumah tangga petani (RTP) adalah 2.838, namun produksinya dari tahun ketahun cenderung terus menurun (BPWC, 2009).

Perkembangan ini menggambarkan akan beberapa hal diantaranya adalah : 
a. Tingginya antusias masyarakat untuk mengelola keramba jaring apung,

b. Tingginya lapangan kerja yang tersedia bagi usaha ini,

c. Semakin beratnya daya dukung waduk dan lingkungan dan

d. Dalam jangka panjang dikhawatirkan nilai guna waduk menjadi menurun dan usaha perikanan tidak berjalan dalam jangka panjang.

Sejumlah penelitian menunjukkan bahwa usaha keramba jaring apung di Waduk Cirata sudah tidak layak lagi baik secara lingkungan maupun sosial. Penggunaan waduk dengan jumlah keramba jaring apung yang melebihi batas yang direkomendasikan (telah melebihi daya dukung waduk dan kelestarian lingkungan) merupakan salah satu penyebab permasalahan yang muncul didalam usaha KJA pada Waduk Cirata. Terus bertambahnya KJA di Waduk Cirata menyebabkan Penurunan kualitas air yang akan memicu pertumbuhan Virus, Bakteri dan Blooming plankton melalui proses eutrofikasi badan air. Sisa - sisa pakan berlebih dari setiap KJA juga dapat mengakibatkan sedimentasi pada dasar waduk atau dengan kata lain dapat dikatakan faktor yang memperpendek usia waduk.

Kematian massal yang sempat melanda dan melumpuhkan usaha budidaya KJA waduk Cirata pada tahun 2002-2005 akibat serangan Koi Virus Herpes (KHV) yang menyebar dari Pembudidaya ikan Koi. Hal ini merupakan sebuah gambaran bahwa kondisi waduk sudah mengalami kerusakan, Penurunan Kualitas air Menyebabkan daya tahan ikan menurun sehingga lebih mudah terserang penyakit. Umumnya pada perairanperairan yang dalam dan arusnya relatif tenang sering ditemukan adanya stratifikasi suhu, mulai dari lapisan suhu yang rendah sampai lapisan suhu yang agak tinggi. Apabila pada bagian permukaan terjadi penurunan suhu yang mendadak, suhu air pun praktis turun sampai di kedalaman tertentu. Pada situasi demikian terjadi pembalikan massa air, yaitu bagian atas bergerak ke bawah dan bagian bawah naik ke permukaan. Kondisi ini semakin dipercepat apabila disertai datangnya angin. Hal ini sempat terjadi pada tahun 2002 keatas. Proses pembalikan masa air itulah yang sering disebut arus balik atau umbalan. Segala nutrien yang membahayakan, seperti NH3, H2S sebagai hasil penguraian dari sisa-sisa pakan dan kotoran yang mengendap akan turut terangkat ke permukaan, membentuk umbalan air berwarna hitam pekat, berbau serta meracuni ikan-ikan budidaya. Pembalikan massa air umumnya terjadi pada saat memasuki awal musim penghujan.

Bukan hanya itu saja, rusaknya lingkungan sekitar DAS Citarum juga membawa dampak buruk terhadap kualitas air waduk Cirata. Penebangan hutan di bagian hulu atau alih fungsi hutan gunung wayang menjadi lahan pertanian serta meningkatnya buangan limbah industri dan rumah tangga semakin memperparah kondisi Waduk Cirata. Tingginya intensitas limbah logam berat industri yang masuk ke Waduk Cirata melalui DAS Citarum, sempat menjadi penyebab kematian massal ikan-ikan budidaya di Waduk Cirata. Limbah logam berat yang masuk ke waduk juga mengakibatkan peningkatan korosi laju turbin PLTA 
$\begin{array}{lcc}\text { sehingga meningkatkan } & \text { biaya } \\ \text { pemeliharaan } & \text { turbin } & \text { Terus }\end{array}$ meningkatnya suhu udara di Waduk Cirata, Jawa Barat dari tahun 2008 hingga 2013, telah membawa dampak terhadap produktivitas perikanan budidaya air tawar di waduk tersebut. .Hal itu mengakibatkan produksi ikan dari kegiatan budidaya keramba jaring apung juga terus menurun dari 13.629 ton tahun 2004 menjadi 5.441 ton tahun 2011. Dengan jumlah KJA 30.850 petak produktifitasnya menurun hingga 176 $\mathrm{kg} /$ petak.

Penataan KJA dalam arti mengurangi jumlah yang ada saat ini tidak bisa dihindari. Menurut Dinas Perikanan Jawa Barat, program penataan ini ditargetkan selesai pada 2015. Khusus Cirata, waduk ini $60 \%$ luasannya berada di wilayah Cianjur, $25 \%$ di bawah Bandung Barat dan 15\% masuk wilayah Purwakarta. Berdasarkan Peraturan Gubernur, hanya 1\% dari luas waduk yang boleh digunakan untuk budidaya perikanan. Dengan luasan yang 6.200 ha, maka untuk Cirata maksimal 62 ha saja yang boleh digarap untuk budidaya. Luasan tersebut untuk ukuran ideal budidaya hanya memuat 12 ribu petak .

\section{KESIMPULAN DAN SARAN}

\section{Kesimpulan}

1. Waduk Cirata memiliki nilai indeks pencemaran 14,4311 maka dapat disimpulkan kondisi kualitas air Waduk Cirata sudah tercemar berat.

2. Beban pencemaran dari Parameter $\mathrm{H}_{2} \mathrm{~S}, \mathrm{NH}_{3}, \mathrm{PO}_{4}, \mathrm{NO}_{3}, \mathrm{NO}_{2}, \mathrm{Hg}, \mathrm{Pb}$, $\mathrm{Cu}$ lebih besar dibanding dengan kapasitas asimilasinya sehingga perairan waduk Cirata tercemar oleh parameter tersebut.

3. Parameter kapasitas asimilasi perairan waduk Cirata yang nilainya lebih besar dari nilai beban pencemarannya adalah parameter TSS, BOD dan COD.

4. Jumlah KJA di waduk Cirata mencapai 51.418 petak dan yang masih operasional sekitar 60 persen atau sebanyak 30.850 petak dengan jumlah rumah tangga petani (RTP) adalah 2.838, namun produksinya dari tahun ketahun cenderung terus menurun.

\section{Saran}

Dari hasil kegiatan penelitian ini disarankan kepada pengelola Waduk Cirata untuk melakukan penataan ulang penempatan dan pemberian ijin penggunaan KJA serta mengurangi jumlah karamba agar beban pencemaran tidak melebihi kapasitas asimilasi perairan waduk Cirata.

\section{DAFTAR PUSTAKA}

BPWC. 2009 . Laporan Hasil Pemantauan Kualitas Air Waduk Cirata

Garno, Y.S.2000. Status dan Strategi Pengendalian Pencemaran Waduk Multiguna Cirata. Prose. Semiloka Nasional : Pengelolaan dan Pemanfaatan Danau dan Waduk. Universitas Pajajaran, Bandung: 7 Nopember 2000. : $126-139$.

Hardjamulia, A., N. Suhenda, Krismono. 1991. Budidaya Ikan Air Tawar dalam Keramba Jaring Apung Mini. Pusat Penelitian dan Pengembangan Perikanan Jakarta. 
Marganof, 2007. Model Pengendalian Pencemaran Perairan di Danau Maninjau Sumatra Barat. IPB. Bogor.

Odum, E.P. 1993. Dasar-Dasar Ekologi Edisi Ketiga. Gajah Mada Universitas Press. Yogyakarta.

Ryding, S.O., W. Rush (Editor). 1989. The Control of Eutrophication of Lakes and Reservoirs. The Parthenon Publishing Group. Paris.
Simarmata, A.R. 2007. Kajian Keterkaitan Antara Cadangan Oksigen Dengan Beban Masukan Bahan Organik di Waduk Ir. H.Djuanda Purwakarta, Jawa Barat (Tesis). Bogor : Institut Pertanian Bogor.

Suhadi, M.F., et.al. 1989. Petunjuk Teknis Budidaya Ikan dalam Karamba Jaring Apung. Badan Penelitian dan Pengembangan Pertanian. Pusat Penelitian dan Pengembangan Perikanan. Jakarta. 